\title{
PREFACE \\ to the Preliminary Edition
}

These materials have been written to meet the needs of students who desire a comprehensive, intensive introduction to Latin forms and syntax in a relatively short period of time. They were originally structured to fit the specific format of the Latin Workshop of the University of California at Berkeley and the Summer Latin Institute of Brooklyn College of the City University of New York. Both of these programs aim to provide a rapid introduction to Latin forms and syntax in a period of approximately four weeks of concentrated study, leading to an additional six weeks in which selected classical and medieval texts are treated in depth. However, this book may also be used, at a slower pace, by instructors of less intensive or regular classes.

The introduction of the subjunctive early in the course will permit the supplementary reading of real or slightly altered texts at an early point in the student's career, given substantial vocabulary and syntactical glosses. Selections of connected reading (real, doctored, or manufactured, as need requires) will be found at the end of each Unit. Notes which will aid in the memorization of vocabulary as well as present some of the rules for word formation are provided after each new vocabulary list. In addition, the book contains a complete appendix, divided into two parts:

1. Forms. All paradigms are included in full for reference and review. This will be particularly helpful in those cases where paradigms are not written out in full in the body of the text (e.g., iste, ista, istud, Unit 12G). The future imperative, which has been omitted from the actual text because of its infrequent use, appears in the appendix for the first time.

2. Syntax. An outline of syntax is presented for reference and review. Each construction is illustrated with several examples and so should supplement amply the explanations and illustrations in the main body of the text. In addition, several constructions which do not appear earlier in the book are included so as to make the text a more useful tool for those students who plan to continue with their study of Latin.

Each Unit was originally designed to be covered in a single day of the Berkeley and Brooklyn intensive summer programs, although regular-paced classes 
may wish to spend an entire week on each one. Drills which illustrate the new morphological and grammatical concepts are supplied in the text for each Unit. Wherever possible, the vocabulary used in these drills has been limited to words which have already been met, and so the drills may be done without knowledge of the new vocabulary in the Unit. The exercises, in whole or in part, should be prepared by the student at home, and the connected readings, with their ample glosses, provide an excellent opportunity for sight reading in class.

The review Units consist of sentences which illustrate the morphological and grammatical principles taught in the lessons being reviewed. In the first three review Units, these sentences are followed by two review tests which the student may work out on his own or with the aid of an instructor. The six sample review tests in the book are followed by answer keys so as to enable the student to use them as a means of self-review. Maximum benefits may be obtained in reviewing the last Units by reading and carefully parsing the selections from Caesar which form the last part of Unit 18. By this time, students should be able to handle, with the aid of vocabulary glosses, any piece of reasonably straightforward Latin prose.

It is the belief of the authors that the best way to understand the structure of Latin is first through literal English translations, then smoother ones. For this reason, literal translations of illustrative sentences are almost invariably given first, followed by smoother English variants. For example,

Fēmina ā militibus vĩsa domum cucurrit.

The woman having been seen by the soldiers ran home; after she had been seen by the soldiers, the woman ran home; since she had been seen by the soldiers, the woman ran home, etc.

Dicit sē fēlīcem esse.

He says himself to be happy; he says that he is happy.

In preparing these materials, the following works have been consulted:

Allen and Greenough, New Latin Grammar (Boston, 1903)

Gildersleeve and Lodge, Latin Grammar (London, 1957)

Krebs and Schmalz, Antibarbarus der Lateinischen Sprache (Basel, 1905)

Lane, A Latin Grammar (New York, 1898)

Woodcock, A New Latin Syntax (London, 1959)

Lewis and Short, A Latin Dictionary (Oxford, 1962) is the authority for the meanings of words; long quantities are for the most part based on those found in Walde-Hofmann, Lateinisches etymologisches Wörterbuch (Heidelberg, 1938).

For help with the present volume, we are grateful to Ms. Judith Rosner for her contributions to the initial stages of the project, to Mr. Robert E. Kenney 
for his kind assistance with xeroxing and duplication, to Ms. Stephanie Russell for help with typing part of the manuscript, and especially to Professors William S. Anderson of the University of California at Berkeley and Charles William Dunmore of New York University for reading through segments of the manuscript and offering many constructive criticisms. In addition, Mr. August Frugé of the University of California Press has been most cooperative and helpful. To Brooklyn College and Professor Ethyle R. Wolfe, Dean of the School of Humanities, go our thanks for encouragement, the opportunity to bring the program to New York City, and for a grant in the summer of 1972 which enabled us to begin the project. Gratitude must also be expressed to those colleagues in the Departments of Classics and Comparative Literature who gave us support, in particular to Professor Anna Griffiths, who has helped us in many ways. Last but not least, it would be remiss of us to conclude without a very special vote of thanks to the department chairman when this was being written, Professor Dennis J. Spininger. If it were not for his eager support of the program, the chances of completing this project would have been diminished severely.

There is one additional group of people, many of whom must remain nameless, who deserve perhaps the most recognition of all - those who have played a role in building the intensive summer Latin programs which inspired this book and for which it was originally written. To Professors W. Ralph Johnson and Alain Renoir of the University of California at Berkeley, Mary-Kay Gamel Orlandi of the University of California at Santa Cruz, John Wyatt of Beloit College, Ms. Catherine R. Freis, current director of the Berkeley Latin Workshop, and Ms. Joan Plotnick and Professor Gail Smith of Brooklyn College go our thanks for their many explicit and implicit contributions to the program and all for which it stands. Most of all, however, we are indebted to the students who have participated in the Berkeley Latin Workshop and the Brooklyn Summer Latin Institute. Their patience and dedication, met only by that of superb teaching staffs, were vital to the success which both programs have enjoyed. It is to them, and to all those who follow them, that this book is dedicated.

Needless to say, the errors and infelicities of style which remain in the following pages are the result of our own short-sightedness and do not bear in the least on the people mentioned above. We hope to iron them out in the final version of the text.

FLOYD L. MORELAND RITA M. FLEISCHER

New York

February, 1974 